\title{
Obtention and characterization of gluten-free baked products
}

\author{
Obtenção e caraterização de produtos panificados livres de glúten
}

\author{
Cristiane SCHAMNE ${ }^{1 *}$, Silvia Deboni DUTCOSKY ${ }^{2}$, Ivo Mottin DEMIATE ${ }^{1}$
}

\begin{abstract}
This work had as objective the development of gluten-free breads and muffins using rice flour and maize and cassava starches. From seven samples resulting from a Simplex-Centroid design, the sensory and instrumental analyses of specific volume, elasticity, and firmness were performed. For the sensory analysis, the optimized formulation contained $50 \%$ of rice flour and $50 \%$ of cassava starch, and for the instrumental evaluation, the optimal simultaneous point for the three conducted analyses were $20 \%$ of rice flour, $30 \%$ of cassava starch, and $50 \%$ of maize starch. A comparative analysis of specific volume, elasticity, firmness, and triangular test was performed with pre-baked, baked, and frozen bread. Physicochemical, nutritional, and microbiological analyses were performed for both bread and muffin according to the Brazilian legislation.

Keywords: bread; muffin; gluten; celiac disease; starch; mixture design.
\end{abstract}

\section{Resumo}

Este trabalho teve como objetivo o desenvolvimento de pães e bolos tipo muffin livres de glúten, usando farinha de arroz e amidos de milho e de mandioca. A partir de sete amostras resultantes de um delineamento Simplex-Centroide, foram realizadas análises sensoriais e instrumentais de volume específico, elasticidade e firmeza. Para a análise sensorial, a formulação ótima de mistura encontrada foi 50\% de creme de arroz e $50 \%$ de amido de mandioca e, para a análise instrumental, o ponto ótimo simultâneo das três análises realizadas foi $20 \%$ de creme de arroz, $30 \%$ de amido de mandioca e 50\% de amido de milho. Análises comparativas foram feitas para volume específico, elasticidade e firmeza, e teste triangular entre o pão assado e o pão pré-assado e congelado. Para ambos os produtos, foram realizadas análises físico-químicas e nutricionais, as quais estão de acordo com a legislação vigente.

Palavras-chave: pão; muffin; glúten; doença celíaca; amido; delineamento de misturas.

\section{Introduction}

Celiac disease is related to the intake of foods containing gluten and causes damage to the surface of the intestinal mucosa, which leads to an inability to use nutrients (ESCOUTO; CEREDA, 2004). According to Tesch (2006), intolerance to wheat, rye, barley, oats, and malt in celiac people makes it impossible the consumption of baked foods, pasta, biscuits, cookies, ice creams, and many other foods. The treatment is based on a gluten-free diet, which makes the intestinal mucosa recover its features and functions restoring the patient's physiological conditions. The diet must be maintained for life since the insistent use of gluten by people with celiac disease can lead to lymphoma and other types of cancer.

The most difficult product to be replaced for celiacs is bread, a basic food of everyday life, and that is the reason why many research groups are interested in this subject worldwide (SUNADA et al, 2003).

Cassava (Manihot esculenta, Crantz) is a low-demanding crop, from which several products are obtained. Flours for human consumption and starch of great commercial interest are made from the roots. From the processing residues, as well as from cassava aerial parts (stems and leaves) fertilizers and animal feed are produced. From a nutritional point of view it is classified as an energetic food, source of calories to be consumed in combination with food protein (EL-DASH; MAZZARI; GERMANI, 1994).

In order to increase the nutritional value of food products in which cassava is used as a substitute for wheat, some sources of protein can be used such as soybean and beans with high protein levels.

In recent years, several researches have been conducted and most significant developments in gluten-free products have been obtained using starches, dairy products, gums and hydrocolloids, probiotics, and other combinations as alternative to gluten, in order to improve the structure, taste, acceptability, and products shelf life (GALLAGHER; GORMLEY; ARENDT, 2003).

The use of frozen bread dough came to meet the demand of consumers for fresh-baked bread, regardless of the time of

Recebido para publicação em 16/7/2008

Aceito para publicação em 23/6/2009 (003676)

${ }^{1}$ Departamento de Engenharia de Alimentos, Universidade Estadual de Ponta Grossa - UEPG, Av. General Carlos Cavalcanti, n. 4748, Campus de Uvaranas, CEP 84030-900,

Ponta Grossa - PR, Brasil, E-mail: crischamne@yahoo.com.br

2 Nutrimental, Rua Marcelino Nogueira, n. 1182, CEP 83005-900, São José dos Pinhais - PR, Brasil

${ }^{*}$ A quem a correspondência deve ser enviada 
purchase, allowing, at the same time, greater flexibility in the production and reducing considerably the work in bakeries (SLUIMER, 1981). According to Meric et al. (1995), the dough pre-fermentation for one or two hours does not affect the resistance of yeast to cycles of freeze-thawing. Rasanen; Härkönen and Autio (1995), examining the dough prefermentation before freezing noted that the loss of bread volume depended on the duration of the pre-fermentation, which is virtually independent of the flour quality. A project developed by a partnership venture-school studied freezing bread dough without fermenting, fermented bread dough without baking, and dough of pre-roasted bread. According to the research, the best results were found with freezing pre-roasted bread dough in addition to the advantage of no need for specialized people to prepare at points of sale (UNIVERSIDADE..., 2007).

The aim of the present work was to test cassava starch, rice flour, and maize starch, with the addition of soybean derivatives for the development of gluten-free breads and muffins targeting a good sensory acceptance and good nutritional value and also considering the freezing of pre-baked products to facilitate commercialization.

\section{Material and methods}

\subsection{Material}

The material used for bread and muffin preparation and their initial formulations are presented in Table 1.

The equipment and materials used to prepare the breads and muffins were a balance, plastic basins, spoons, a stand mixer brand $\mathrm{Arno}^{\circ}$, and an industrial oven brand Perfecta (model Vipão ${ }^{\circ}$. After baking, the breads and muffins were evaluated in terms of volume (volume meter brand Vondel ${ }^{\circ}$, model VDMV- $03^{\circ}$ ) and texture (Stable Micro System Texture Analyzer TA.XT2, software:

Table 1. Initial formulations for gluten-free bread and muffins, described as \% in relation to starches and flour.

\begin{tabular}{|c|c|c|}
\hline & \multicolumn{2}{|c|}{$\%$ in relation to starches and flour } \\
\hline & $\begin{array}{c}\text { Gluten-free } \\
\text { bread }\end{array}$ & $\begin{array}{l}\text { Gluten-free } \\
\text { muffin }\end{array}$ \\
\hline Rice flour Yoki & 59.56 & 83.33 \\
\hline Cassava starch Pinduca ${ }^{\circledR}$ & 33.78 & 16.67 \\
\hline Maize starch Maizena ${ }^{\star}$ & 6.66 & - \\
\hline Refined sugar União ${ }^{\circledR}$ & 5.35 & - \\
\hline Brown sugar Guimarães ${ }^{\circledast}$ & - & 25.13 \\
\hline Iodized salt ground MaisVita ${ }^{\circledR}$ & 1.24 & 2.05 \\
\hline Biological dry yeast Fleishmann, & 2.19 & - \\
\hline Chemical baking powder Royal $^{\oplus}$ & - & 8.97 \\
\hline${ }^{\star}$ Ice cream neutral mixture Selecta ${ }^{\circ}$ & 0.93 & - \\
\hline Eggs & 18.80 & 115.38 \\
\hline Margarine without salt Doriana ${ }^{\circledR}$, & 4.72 & 41.03 \\
\hline Soybean extract powder Vitao ${ }^{\oplus}$ & 5.80 & 21.79 \\
\hline $\begin{array}{l}{ }^{*} \text { Cake and ice cream emulsifying } \\
\text { Nutral }^{\circ}\end{array}$ & 2.00 & 0 \\
\hline Cinnamon powder Yoki ${ }^{\circledast}$ & - & 2.50 \\
\hline Chocolate in pieces Garoto $^{\circ}$ & - & 83.85 \\
\hline
\end{tabular}

${ }^{*}$ Ice cream neutral mixture: guar gum and carboxymethylcellulose/Emulsifying: Monoglycerides of fatty acids distillates, sorbitana monostearate and polysorbate 60 . texture expert exceed). The analysis of the specific volume included the use of a semi-analytical balance, volume meter, and standard wood volume of $1850 \mathrm{~cm}^{3}$ and mustard seeds.

\section{Production of the gluten-free breads}

For the preparation of gluten-free breads, maize starch, rice flour, and cassava starch were mixed with sugar, salt, yeast, ice cream neutral mixture and soybean extract powder. The margarine and emulsifier were melted in a water-bath and added to the mixture together with eggs. Water was poured into the dough until it reached the proper consistency. The dough was shaped, put in proper recipients, and placed in the oven at $40^{\circ} \mathrm{C} / 1$ hour for development. Next, the top of the breads were evenly brushed with egg yolk, brought to the oven and baked at $180^{\circ} \mathrm{C} / 30$ minutes. After cooling, the breads were wrapped in appropriate plastic packaging.

For the frozen pre-baked breads, the dough remained in the oven at $180{ }^{\circ} \mathrm{C}$ for fifteen minutes. After that, the bread was allowed to cool, wrapped in appropriate plastic packaging, and frozen $\left(-18^{\circ} \mathrm{C}\right)$. After 30 days, the breads were removed from the freezer and immediately baked in an oven at $180^{\circ} \mathrm{C} / 20$ minutes.

The use of cassava starch in the bread formulations was restricted to a maximum of $50 \%$ of the amount of flour used due to technological limitations such as producing sticky crumb and low volume breads.

For the development of bread, using the software STATISTICA 7.0, the restriction of a maximum of $50 \%$ of cassava starch was imposed, which resulted in the design blends originating seven samples, shown in Table 2. This design was selected through the combination of five experimental points, located in the vertex, and a centroid point with true repetition.

\section{Production of the gluten-free muffins}

Margarine and brown sugar were mixed. Then, cassava starch, rice flour, yeast, eggs, cinnamon powder, and pieces of chocolate were added. The dough was placed into the paper mini cups and then baked in an oven at $180{ }^{\circ} \mathrm{C} / 30$ minutes. After this, the muffins were removed from the oven, cooled to room temperature, and put into plastic packaging.

For the pre-baked and frozen muffins, the dough was baked in the oven for only 15 minutes. After this period, the muffins were removed from the oven, cooled to room temperature, put

Table 2. Design of dough preparation for the seven samples.

\begin{tabular}{cccc}
\hline Samples & ${ }^{*}$ CAS & ${ }^{\star}$ RIF & ${ }^{\star}$ MAS \\
\hline 1 & - & $100 \%$ & - \\
2 & - & - & $100 \%$ \\
3 & & $50 \%$ & $50 \%$ \\
4 & $50 \%$ & $50 \%$ & - \\
5 & $50 \%$ & - & $50 \%$ \\
6 & $25 \%$ & $37.5 \%$ & $37.5 \%$ \\
7 & $25 \%$ & $37.5 \%$ & $37.5 \%$ \\
\hline
\end{tabular}

* CAS: Cassava Starch/RIF: Rice Flour/MAS: Maize Starch. 
into plastic packaging, and then frozen at $-18^{\circ} \mathrm{C}$. After 30 days, the dough was removed from the freezer and immediately baked in an oven at $180^{\circ} \mathrm{C} / 20$ minutes. Lastly, the muffin was removed from the oven, cooled to room temperature, and put into plastic packaging.

\section{Instrumental analysis}

The gluten-free breads and muffins were evaluated using selected instrumental analyses considering their specific volume, firmness, and elasticity. Analyses of specific volume were performed in triplicate, and the analyses of elasticity and firmness were made using five samples.

For the specific volume analysis, a special device for bread volume measurement was used, almost $1850 \mathrm{~cm}^{3}$ of mustard seed for the measurement. The technique is based on determination of bread volume by seed displacement. The specific volume was expressed in $\mathrm{cm}^{3} \cdot \mathrm{g}^{-1}$. To measure the firmness and elasticity, the samples were sliced with thickness of $2.5 \mathrm{~cm}$. The equipment used was a Stable Micro System Texture Analyzer TA.XT2 ${ }^{\circledR}$ with an acrylic probe of $36 \mathrm{~mm}$ in diameter, which has high sensitivity to convey all the measured data to a coupled computer with the program Texture Expert Exceed ${ }^{\circledR}$.

For the breads, instrumental analyses of seven samples resulting from the experimental design were performed: of the optimal point obtained by sensorial analysis, the optimal simultaneous point obtained by instrumental analysis, and the pre-baked and frozen sample of the preferred test obtained from the second sensorial analysis. For the muffins, the instrumental analyses were performed for the developed sample and for that pre-baked and frozen sample.

\section{Sensory analysis of gluten-free breads}

Before starting the development of the project that resulted in this paper, the approval of the Ethics Committee of the University of Ponta Grossa, Brazil (process number 26/2006) obtained, and all the participants signed the consent.

The breads were submitted to the sensory analysis through a hedonic scale test of nine points $(1=$ disliked extremely, $9=$ liked extremely). Each taster received one slice of bread each per test as well as a tray containing the coded samples with three digits at random. Four sensory analyses were performed in order to obtain the best possible formulation from the tests The first sensory analysis was performed with the seven samples of bread resulting from the design of starches, by 90 untrained tasters, $26.44 \%$ male and $73.56 \%$ female, who did not suffer from celiac disease.

A second analysis was performed for the optimal point reached in the first sensory analysis and the optimal simultaneous point resulting from instrumental analyses of specific volume, elasticity, and firmness. This sensory evaluation was carried out by 93 untrained tasters, $34.07 \%$ male and $65.93 \%$ female, who did not suffer from celiac disease.

The last sensory analysis was performed by people who suffered from celiac disease in order to verify their acceptability of the sensory preferred gluten-free breads as defined by the common tasters. This test was carried out in the Paraná State Celiac Association (ACELPAR) with the participation of 17 untrained celiac tasters, $24 \%$ males and $76 \%$ females.

\section{Sensory analysis of gluten-free muffins}

For the sensory analysis of the muffins, only the original formulation was used with the participation of 122 untrained tasters, $44.17 \%$ male and $55.83 \%$ female, who did not from celiac disease and also with 17 celiac tasters, 24\% males and 76\% females, at the Paraná State Celiac Association (ACELPAR).

After obtaining the sensory preferred formulation of the bread, from the optimal point of the first sensory analysis and the optimal simultaneous point resulting from instrumental analyses, the bread and the muffin samples were pre-baked and frozen. These samples were also evaluated for sensory analysis using the triangular test with the participation of 12 selected and trained tasters. The objective of this test was to verify whether there was a significant difference between baked, pre-baked and frozen bread and muffin samples.

\section{Physicochemical analysis}

From the preferred formulation of bread in the second sensory analysis and unique sample of muffin, physicochemical analyses were performed, including moisture, crude protein, lipids, dietary fiber, carbohydrates, trans and saturated fats, mineral residue, sodium, calcium, and iron. All analyses were performed in duplicate. The analysis of dietary fiber was performed in accordance with the method of the AOAC (ASSOCIATION..., 1997). Analyses of calcium, iron and sodium were performed using the method described by AOAC (ASSOCIATION..., 2000). The other tests were conducted in accordance with the methods for analysis of foods of the Instituto Adolfo Lutz (1985).

\section{Results and discussions}

\subsection{Gluten-free breads}

In Figure 1, the seven samples of the starch design are presented.

The arithmetic averages of hedonic scale obtained from 90 tasters, participants of the first sensory analysis, are presented in Table 3.

In order to find the best formulation for the gluten-free bread, with a mixture of the three sources of starch, the linear model of Scheffé was used. The model presented an adjusted coefficient of determination $\left(\mathrm{R}_{\mathrm{aj}}^{2}\right)$ of $71.4 \%$. Although this factor did not present a too high value, the model did not lack adjustment ( $\mathrm{p}=0.2936)$; therefore, the model can be considered significant for predictive purposes $(\mathrm{p}=0.03632)$ since $\mathrm{p}<0.05$. The canonical equation of Scheffé for sensory preference of consumers, presented in Table 4, was used to generate the triangular diagram shown in Figure 2.

Cassava starch and rice flour presented stronger effects on the preference as demonstrated by the higher coefficients showed in the equation of Table 4. 


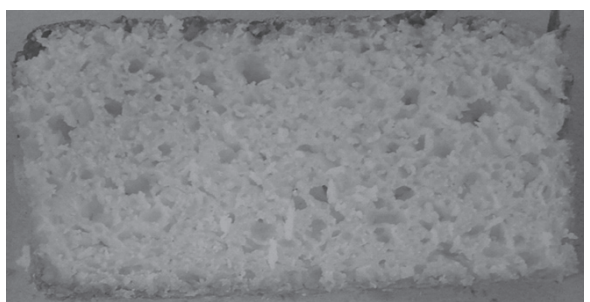

Test 01

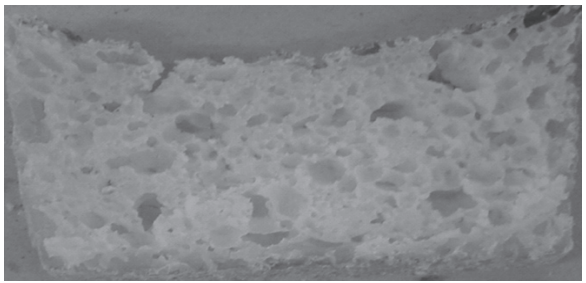

Test 04

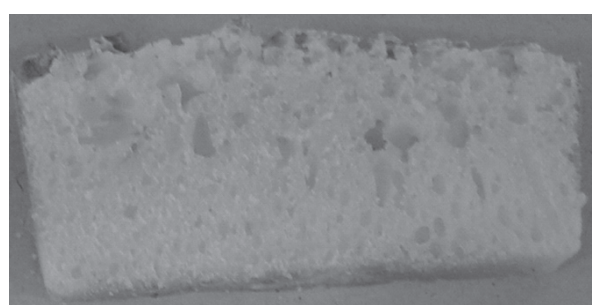

Test 02

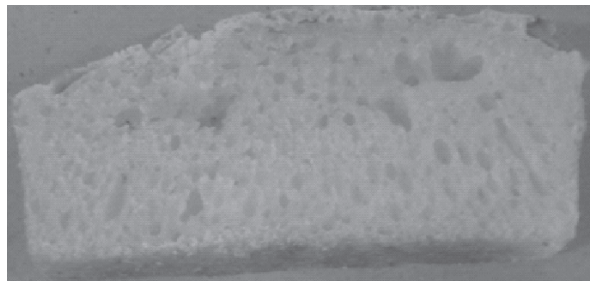

Test 05

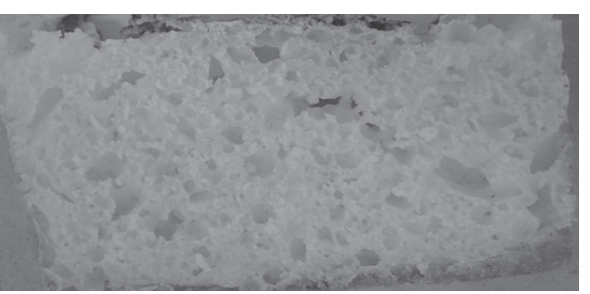

Test 07

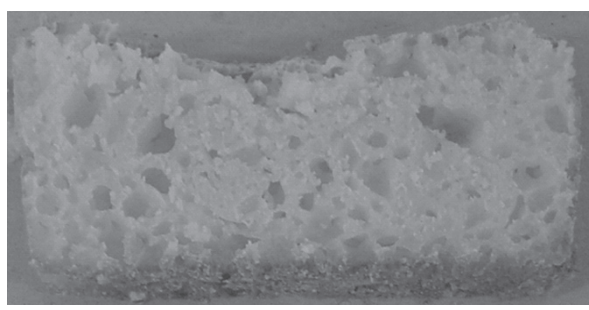

Test 03

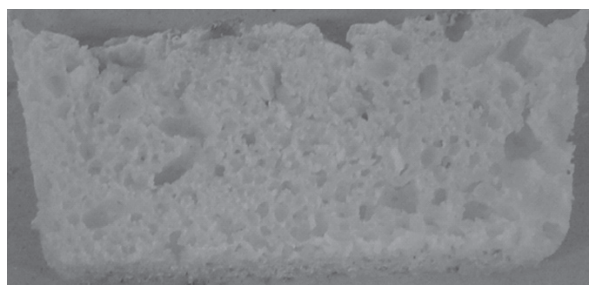

Test 06

Figure 1. Gluten-free breads: starch design samples.

Table 3. Average and standard deviation for the hedonic scale, specific volume $\left(\mathrm{cm}^{3} \cdot \mathrm{g}^{-1}\right)$, elasticity $(\%)$, and firmness $(\mathrm{g})$ tests in each test performed resulting from the starches design.

\begin{tabular}{cccccccc}
\hline Test & RIF (\%) & CAS (\%) & MAS (\%) & \multicolumn{4}{c}{ Results } \\
\cline { 4 - 7 } & & & & Hedonic scale & Specific volume $\left(\mathrm{cm}^{3} \cdot \mathrm{g}^{-1}\right)$ & Elasticity $(\%)$ & Firmness $(\mathrm{g})$ \\
\hline 1 & 100 & 0 & 0 & $5.02 \pm 2.25^{\mathrm{bc}}$ & $1.20 \pm 0$ & $46.88 \pm 1.98$ & $3587.60 \pm 1330.48$ \\
2 & 0 & 0 & 100 & $4.66 \pm 2.14^{\mathrm{bc}}$ & $2.65 \pm 0.21$ & $43.10 \pm 4.30$ & $1491.48 \pm 457.13$ \\
3 & 50 & 0 & 50 & $5.14 \pm 2.12^{\mathrm{b}}$ & $1.40 \pm 0$ & $45.80 \pm 2.07$ & $3968.04 \pm 202.50$ \\
4 & 50 & 50 & 0 & $6.17 \pm 2.02^{\mathrm{a}}$ & $1.20 \pm 0$ & $48.48 \pm 3.02$ & $3254.50 \pm 188.76$ \\
5 & 0 & 50 & 50 & $5.79 \pm 2.02^{\mathrm{ab}}$ & $2.45 \pm 0.21$ & $58.34 \pm 1.85$ & $1207.32 \pm 95.42$ \\
$6^{*}$ & 37.5 & 25 & 37.5 & $6.00 \pm 1.94^{\mathrm{a}}$ & $1.60 \pm 0$ & $49.96 \pm 1.59$ & $2859.20 \pm 523.51$ \\
$7^{*}$ & 37.5 & 25 & 37.5 & $5.78 \pm 1.94^{\mathrm{ab}}$ & $1.70 \pm 0$ & $50.84 \pm 2.38$ & $2992.28 \pm 582.78$ \\
\hline
\end{tabular}

RIF $=$ Rice Flour; CAS $=$ Cassava Starch; MAS $=$ Maize Starch; ${ }^{*}$ Arithmetical average \pm Standard deviation; ${ }^{*}$ Averages in the same column with different letters differ by Tukey test $(\mathrm{p}<0.05) ;{ }^{*}$ Central point/Repetition of the true focal point.

The equation demonstrated in Table 4 was used to generate the triangular diagram shown in Figure 2 for the hedonic scale.

Samples with higher preference (> 6.4) were obtained in the experimental area with a higher proportion of Cassava Starch (CAS).

Applying the optimization technique of Derringer-Suich and the exhaustive computer imposition of grid points, the optimal formulation mixture (Equation 1) was detected:

$50 \% \mathrm{RIF}+50 \% \mathrm{CAS}$

Table 3 shows the arithmetic averages obtained in the instrumental analyses of specific volume $\left(\mathrm{cm}^{3} \cdot \mathrm{g}^{-1}\right)$, elasticity (\%), and firmness (g).
In order to obtain the optimization of gluten-free bread, with a mixture of three flours, the Scheffe's quadratic model was used for instrumental analyses. As can be seen in Table 4, the models presented are highly significant for the three parameters studied since $\mathrm{p}<0.05$ and the adjusted coefficient of determination $\left(\mathrm{R}^{2}{ }_{\mathrm{aj}}\right)$ is 99.27 for specific volume, $98.52 \%$ for elasticity, and $98.79 \%$ for firmness. The models do not show lack of fit.

In the present study, the adjustment of the second order to the specific volume indicated that maize starch is the variable that most influenced this characteristic. The interaction between rice flour and cassava starch was not significant for the specific volume of bread. According to the equation in Table 4, it can be observed that the binary system maize starch $\times$ cassava starch exerted positive influence increasing the specific volume 


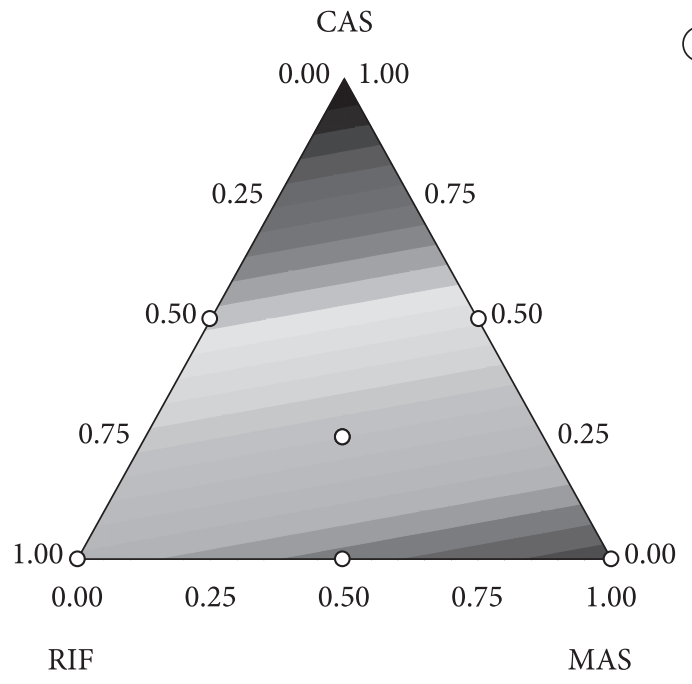

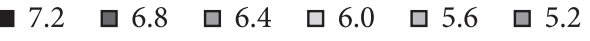

(a)

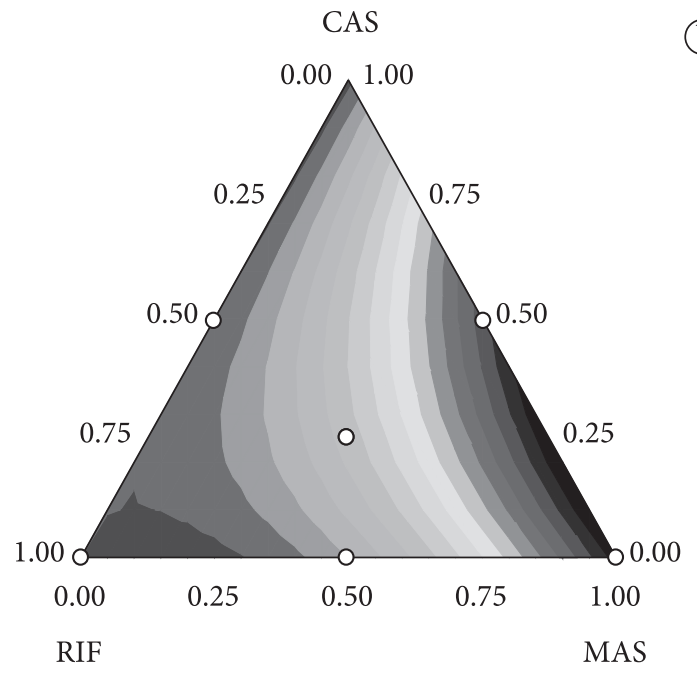

2.6
$\square$ $2.4 \quad \square 2.2 \quad \square 2.0 \quad \square 1.8 \quad \square 1.6 \quad \square 1.4$

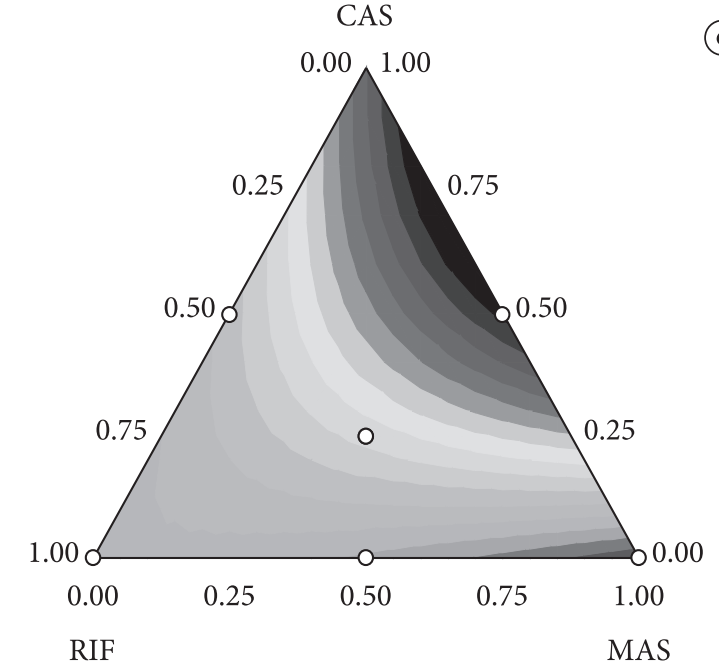

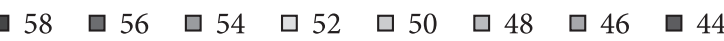

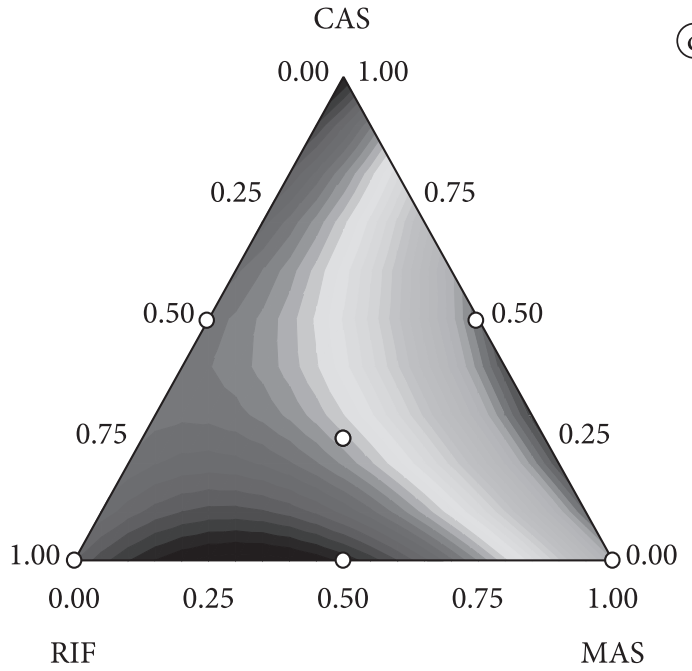

$4000 \square 3500 \quad \square 3000 \quad \square 2500 \quad \square 2000 \quad \square 1500 \quad \square 1000$

Figure 2. Triangular diagram of the: a) hedonic scale; b) specific volume; c) elasticity; d) firmness of bread for mixtures containing Rice Flour (RIF), Maize Starch (MAS), and Cassava Starch (CAS) resulting from the starches design.

Table 4. Models and statistical analysis obtained from the bread preference parameters, for the parameters of specific volume $\left(\mathrm{cm}^{3} \cdot \mathrm{g}^{-1}\right)$, elasticity $(\%)$, and firmness (g) resulting from the starch design.

\begin{tabular}{llll}
\hline \multicolumn{1}{c}{ Equation } & $\mathrm{R}_{\mathrm{aj}}^{2}(\%)$ & $\mathrm{p}^{\mathrm{a}}$ & Lack of adjustment $(\mathrm{p})$ \\
\hline Ypreference $=$ 5.26RIF + 4.82MAS + 7.23CAS & 71.4 & 0.03632 & 0.29360 \\
Yvolume = 1.20RIF + 2.65MAS + 1.20 CAS -2.09RIF $\times$ MAS + 2.11MAS $\times$ CAS & 99.27 & 0.004889 & 0.957485 \\
Yelasticity = 47.03RIF + 43.13MAS + 49.80CAS + 46.32 MAS $\times$ CAS & 98.52 & 0.001073 & 0.609377 \\
Yfirmness = 3583.2RIF + 1504.7MAS + 2890.6 CAS + 5380.1RIF $\times$ MAS - 4172.23MAS $\times$ CAS & 98.79 & 0.008718 & 0.378106 \\
\hline
\end{tabular}

of bread, whereas the binary system rice flour $\times$ maize starch showed an antagonistic effect reduced the specific volume of the product.

The adjustment of the second order to the elasticity indicated that cassava starch was the variable that most influenced the elasticity of the gluten-free bread. The interactions between rice flour and cassava starch and from rice flour and maize starch were not significant for the bread elasticity. The binary system maize starch $\times$ cassava starch exerted positive influence on the elasticity increasing this characteristic in the product.

The adjustment of the second order to the firmness indicated that the rice flour is the variable that most influenced 
the firmness of the gluten-free bread. The interaction between rice flour and cassava starch was not significant for the firmness of bread. According to the equation illustrated in Table 4, it can be observed that the binary system rice flour $\times$ maize starch had positive influence on the firmness of bread increasing this characteristic in the product, whereas the combination of maize starch $\times$ cassava starch demonstrated an antagonistic effect, reducing the firmness of the product.

The equations demonstrated in Table 4 were used to generate the triangular diagram shown in Figure 2 for the hedonic scale (a), specific volume (b), elasticity (c), and firmness (d).

Applying the optimization technique of Derringer-Suich and the exhaustive computer imposition of grid points, for a point to point comparison, the best formulations for mixture found for the analyses of specific volume, elasticity, and firmness (Equations 2, 3 and 4, respectively) were:

$75 \% \mathrm{MAS}+25 \% \mathrm{CAS}$

$50 \%$ MAS + 50\% CAS

$75 \% \mathrm{RIF}+22.2 \% \mathrm{MAS}+2.8 \% \mathrm{CAS}$

In order to obtain the optimal point simultaneously between instrumental analyses of specific volume, elasticity, and firmness of bread, the technique of Derringer-Suich optimization and the imposition of a comprehensive computational of a grid of points were applied, for a point to point comparison, and the best mixture formulation (Equation 5) found was the following:

$20 \% \mathrm{RIF}+50 \% \mathrm{MAS}+30 \% \mathrm{CAS}$

The formulation of the optimized bread in the first sensory analysis showed satisfactory results such as pleasant taste, soft and uniform structure, but it was compact low volume. The formulation of the optimized bread from the instrumental analyses presented pleasant taste, tenderness, uniform appearance, and good growth, presenting visual characteristics closer to the conventional bread, made from wheat flour. Based on this fact, a second sensory analysis was carried out using the formulation of the two optimal points as sample. Figure 3 shows these points.

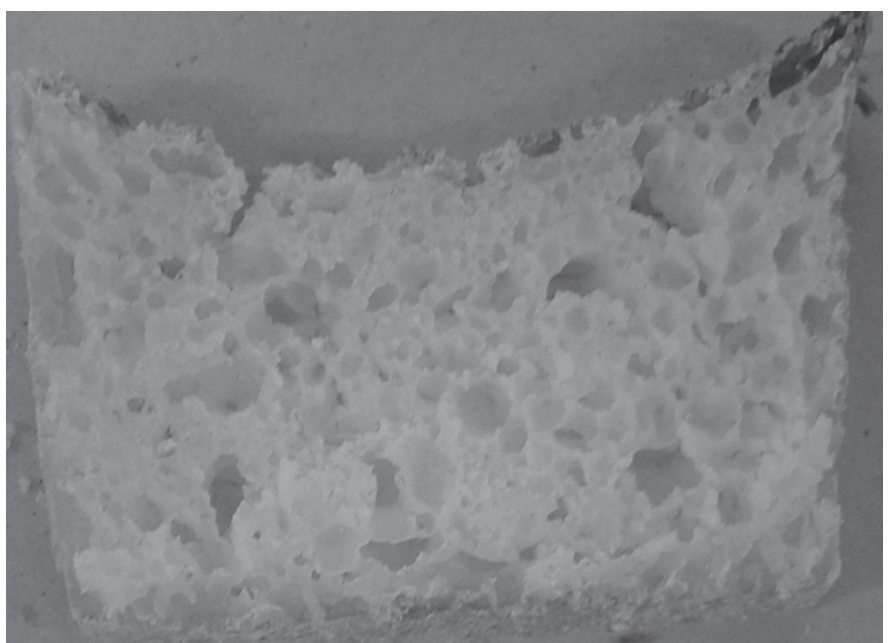

Test $01: 50 \%$ CAR + 50\%AMA
The analysis of variance (ANOVA) was applied to the results and found that there was significant difference between the acceptability of the samples at $5 \%$ level.

Next, the sensory test was carried out with those with celiac disease using only the most accepted formulation by common consumers (not celiacs), which was the formulation consisting of $20 \%$ of rice flour, $30 \%$ of cassava starch, and $50 \%$ of maize starch.

The arithmetic average of the hedonic scale obtained from 17 celiac tasters was $6.71 \pm 1.69$. The sample showed an average higher 5.0 in the region of acceptability.

A comparative analysis of the hedonic scale, specific volume, elasticity, and firmness for two optimal points obtained was carried out, according to Table 5.

A study conducted by Esteller and Lannes (2005) on complementary parameters for fixing identity and quality of baked products, in which different brands of conventional bread were analyzed, was taken as a benchmark for the comparison to the instrumental results of specific volume, elasticity, and firmness of the preferred gluten-free bread in the sensory analysis. The results obtained for the preferred gluten-free bread by sensory evaluation, considering the parameters specific volume, elasticity, and firmness $\left(1.94 \mathrm{~cm}^{3} . \mathrm{g}^{-1}, 54.84 \%\right.$ and $1285.42 \mathrm{~g}$, respectively) were lower than those obtained in the study conducted by Esteller and Lannes (2005) for conventional bread, $\left(4.10 \mathrm{~cm}^{3} \cdot \mathrm{g}^{-1}, 89 \%\right.$ and $1560 \mathrm{~g}$, respectively). Due to the formation of the gluten network in the conventional bread, there was greater retention of gas produced by fermentation, which resulted in a bulkier structure. The greater elasticity of the conventional bread is related to the presence of glutenine, protein constituent of the gluten and responsible for the elasticity of the dough. Due to the structure of network formed by the gluten protein (gliadine and glutenine), the conventional product presented higher firmness than that of the product without gluten in its formulation.

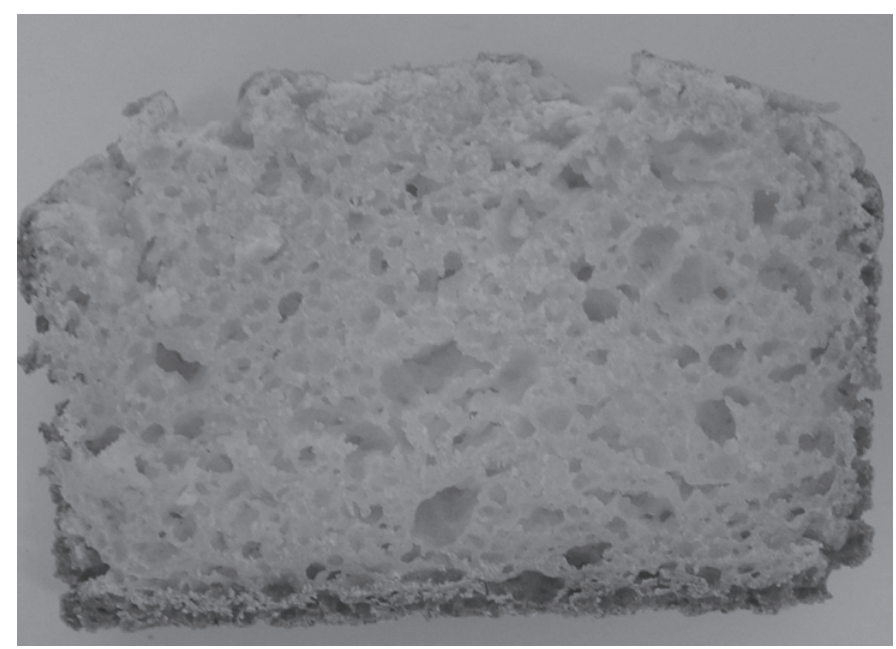

Test 02: 20\%CAR+30\%AMA+50\%AMI

Figure 3. Samples of the two best points. 


\subsection{Gluten-free muffins}

A muffin sample that was submitted to sensory evaluation is illustrated in Figure 4.

The arithmetic average of the hedonic scale obtained with 122 common tasters (not celiac) was $7.76 \pm 1.07$, and with 17 celiac tasters it was $8.35 \pm 0.79$. The sample average in the region of acceptability for the two analyses was higher than 5.0.

The averages of specific volume $\left(\mathrm{cm}^{3} \cdot \mathrm{g}^{-1}\right)$, elasticity (\%), and firmness $(\mathrm{g})$ were $1.895 \pm 0.025,44.656 \pm 2.034$, and $2382.56 \pm 633.24$, respectively.

For the results of the instrumental analyses of specific volume, elasticity, and firmness of gluten-free muffin, a study conducted by Esteller; Zancanaro Junior and Lannes (2006) on chocolate cake made with powder of cupuaçu (Theobroma grandiflorum) and kefir was used as a benchmark for a comparison of instrumental results of specific volume, elasticity, and firmness of the gluten-free muffin using the control formulation without cupuassu or kefir as a parameter. The

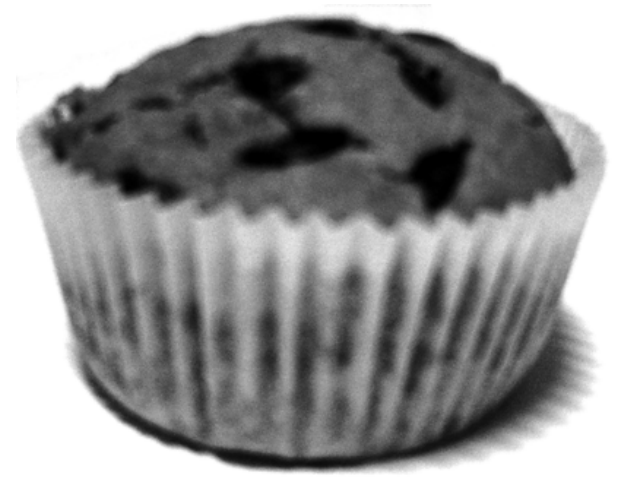

Figure 4. A muffin sample. results for the gluten-free muffin, considering the parameters specific volume, elasticity, and firmness $\left(1.895 \mathrm{~cm}^{3} \cdot \mathrm{g}^{-1}, 44.656 \%\right.$ and $2382.56 \mathrm{~g}$, respectively) were lower than those reported by Esteller, Zancanaro Junior and Lannes (2006) for chocolate cake $\left(2.03 \mathrm{~cm} 3 . \mathrm{g}^{-1}, 74 \%\right.$ in $3810 \mathrm{~g}$, respectively). Due to the network formation of gluten in the conventional cake, there was greater retention of gas from fermentation and therefore a bulkier structure. The greater elasticity presented by the conventional cake is related to the presence of glutenine, protein constituent of gluten, and it is responsible for the elasticity of the dough. Due to the structure of the network formed by the gluten protein (gliadine and glutenine), the conventional product presents greater firmness than the product without gluten in its formulation.

\subsection{Purchase intention among common and celiac consumers}

In order to verify the acceptance of bread and muffin, the purchase intention among common consumers and celiac consumers was also verified, as shown in Table 6.

\subsection{Comparison between gluten-free baked bread and muffin and gluten-free bread and pre-baked and frozen muffin}

In order to verify if the freezing of the bread and muffin affects the characteristics of the products in terms of specific volume, elasticity, and firmness and sensory characteristics, comparative tests were conducted between a sample of baked bread and muffin and a sample of bread and pre-baked and frozen muffin using only the sensorial preferred formulations of gluten-free bread (20\% RIF, 30\% MAS and 50\% CAS) and the unique formulation of muffin.

Table 7 shows the results obtained in the instrumental analyses for the baked bread and the pre-baked and frozen bread.

Table 5. Average and standard deviation of the hedonic scale, specific volume $\left(\mathrm{cm}^{3} \cdot \mathrm{g}^{-1}\right)$, elasticity (\%), and firmness $(\mathrm{g})$ of bread resulting from the two best points.

\begin{tabular}{ccc}
\hline Test & 01 & 02 \\
\hline Composition & 50\%RIF, 50\%CAS & $20 \%$ RIF, 30\%CAS, 50\%MAS \\
\hline Hedonic scale results & $5.77 \pm 1.83^{\mathrm{b}}$ & $6.96 \pm 1.71^{\mathrm{a}}$ \\
Specific volume results $\left(\mathrm{cm}^{3-} \cdot \mathrm{g}^{-1}\right)$ & $1.20 \pm 0.00^{\mathrm{b}}$ & $1.940 \pm 0.044^{\mathrm{a}}$ \\
Elasticity results (\%) & $48.48 \pm 3.015^{\mathrm{b}}$ & $54.84 \pm 3.438^{\mathrm{a}}$ \\
Firmness results (g) & $3254.5 \pm 188.76^{\mathrm{a}}$ & $1285.42 \pm 247.18^{\mathrm{b}}$ \\
\hline
\end{tabular}

RIF $=$ Rice flour CAS $=$ Cassava starch MAS $=$ Maize starch $;{ }^{*}$ Arithmetical average \pm Standard deviation; ${ }^{*}$ Averages in the same line with different letters differ overridden by Tukey test $(\mathrm{p}<0.05)$.

Table 6. Purchase intention among common and celiac consumers.

\begin{tabular}{|c|c|c|c|c|}
\hline \multirow[t]{2}{*}{ Purchasing intention } & \multicolumn{2}{|c|}{ Common tasters } & \multicolumn{2}{|c|}{ Celiac tasters } \\
\hline & Bread (\%) & Muffin (\%) & Bread (\%) & Muffin \\
\hline Certainly would buy the products & 28.57 & 38.52 & 35.29 & 58.82 \\
\hline Probably would buy the products & 36.73 & 50 & 29.41 & $35.29 \%$ \\
\hline Perhaps would purchase, perhaps would not purchase the product & 20.41 & 11.48 & 29.41 & $5.88 \%$ \\
\hline Probably would not buy the products & 14.29 & 0 & 5.88 & $0 \%$ \\
\hline
\end{tabular}


The development of the pre-baked product before freezing is the main responsible for the maintenance of volume in the frozen product. Since the process of fermentation and consequent growth of the bread had already occurred, it does not compromise the activity of the yeast. Moreover, the use of emulsifier, composed of monoglycerides of distilled acids, sorbitane monoesterate, and polysorbate 60 , improves the aeration of the dough, which directly influences in the volume of the product. While they are positioned at the interface between fat and the aqueous phase, the emulsifying also reduces the surface tension between the aqueous phase and air allowing greater and faster incorporation of air into the dough keeping the product stable for a longer time (PAVANELLI; CICHELLO; PALMA, 2000).

The difference regarding the elasticity between the baked product and the pre-baked and frozen product may be related to the starch retrogradation. During the baking of bread, when the starch begins to be heated in the presence of water, the bridges of intermolecular hydrogen are broken allowing water penetration into the micelles. The continuous heating in the presence of plenty of water results in the total loss of crystalline areas, and the starch becomes transparent when the gelatinization temperature is reached (BOBBIO, F. O,; BOBBIO, P. A., 2003). When the temperature is reduced during the cooling of the product, the starch chains tend to interact more closely with each other forcing the water out resulting in syneresis. The freezing process is based on the physical principle of the water separation of the dough and results from the formation of ice crystals below $0{ }^{\circ} \mathrm{C}$ (LAAKSONEN; ROOS, 2000). It is believed that the damage on the dough, associated with the processes of ice-melting, is induced by the formation of ice crystals (VARRIANO-MARSTON; HSU; MAHDI, 1980).

Table 8 shows the results obtained in the instrumental analyses of baked muffin and the pre-baked and frozen muffin, composed by $83.33 \%$ of rice flour and $16.69 \%$ of cassava starch and $50 \%$ of maize starch.

The baking powder used for the preparation of the muffin was composed of sodium bicarbonate $\left(\mathrm{NaHCO}_{3}\right)$, which, by the influence of heat and moisture, produces gaseous $\mathrm{CO}_{2}$ detachment capable of expanding batters elaborated with flour or starch increasing the volume and porosity. No type of emulsifying was used in the production of muffin, which besides positioning the interface between fat and gas, it also reduces the surface tension between the aqueous phase and air allowing greater and more rapid incorporation of the air dough. When the air is introduced into the batter during the beating, a protein derived mainly from egg white undergoes deployment and the lipophilic tails point up into the gas phase, towards the interior of the air bubbles, and its hydrophilic portion remains in the aqueous phase. This protein film also acts in the formation and stabilization of the foam, along with the molecules of emulsifiers. The presence of emulsifiers in the oil-water interface indirectly helps the aeration because the emulsifier prevents the contact of fat with protein, which could destabilize the protein film (PAVANELLI; CICHELLO; PALMA, 2000). Since no type of emulsifier was used in the production of the muffin, the fat present in the product may have come into contact with protein destabilizing the film of protein and thus reducing the stability of the product during the time of freezing.

The content of amylose in maize starch and rice starch is around 25 and $16 \%$, respectively (BOBBIO, F. O,; BOBBIO, P. A., 2003), and in the cassava starch it varies from 17 to $18 \%$ (SARMENTO, 1997). The retrogradation of starch, resulting from the attraction of molecules and formation of hydrogen bridges during cooling, occurs more easily between the molecules of amylose due to its linear structure, whereas in amylopectin the phenomenon probably does not occur only in the periphery of the molecules. Since in the muffin formulation only rice flour and cassava starch which contain lower levels of amylose when compared to maize starch were used, the starch retrogradation was lower, and consequently the process of syneresis and also the formation of ice crystals. This fact may be linked to the damage reduction of product texture. Moreover, according to Bobbio, F. O and Bobbio, P. A. (2003), high concentrations of sugar reduce the gelatinization rate of starch. Sugars reduce the strength of the gel because they connect to water thus decreasing the amount of free water because they compete over the water that would connect to starch, thereby interfering in the formation of the structure of the gel. The lipids also affect gelatinization of starch, because the fats are combined with amylose slowing the absorption of water by starch granules (BOBBIO, F. O,; BOBBIO, P. A., 2003).

Table 7. Averages and standard deviation for specific volume $\left(\mathrm{cm}^{3} \cdot \mathrm{g}^{-1}\right)$, elasticity (\%), and firmness $(\mathrm{g})$ of sample of baked and pre-baked and frozen bread.

\begin{tabular}{lccc}
\hline \multirow{2}{*}{ Sample } & \multicolumn{3}{c}{${ }^{*}$ Results } \\
\cline { 2 - 4 } & Specific volume $\left(\mathrm{cm}^{3} \cdot \mathrm{g}^{-1}\right)$ & Elasticity $(\%)$ & Firmness $(\mathrm{g})$ \\
\hline Baked & $1.945 \pm 0,044^{\mathrm{a}}$ & $54.836 \pm 3.438^{\mathrm{a}}$ & $1285.42 \pm 247.182^{\mathrm{a}}$ \\
Pre-baked and frozen & $1.790 \pm 0.150^{\mathrm{a}}$ & $46.214 \pm 3.310^{\mathrm{b}}$ & $1579.18 \pm 259.373^{\mathrm{a}}$ \\
\hline
\end{tabular}

${ }^{\star}$ Arithmetical average \pm Standard deviation; ${ }^{*}$ Averages in the same column with different letters differ overridden by Tukey test $(\mathrm{p}<0.05)$.

Table 8. Averages and standard deviation for specific volume $\left(\mathrm{cm}^{3} \cdot \mathrm{g}^{-1}\right)$, elasticity $(\%)$ e firmness $(\mathrm{g})$ of baked muffin sample and pre-baked and frozen muffin sample.

\begin{tabular}{lccc}
\hline \multirow{2}{*}{ Sample } & \multicolumn{3}{c}{${ }^{\mathrm{x}}$ Results } \\
\cline { 2 - 4 } & Specific volume $\left(\mathrm{cm}^{3} \cdot \mathrm{g}^{-1}\right)$ & Elasticity $(\%)$ & Firmness $(\mathrm{g})$ \\
\hline Baked & $1.895 \pm 0.025^{\mathrm{a}}$ & $44.656 \pm 2,034^{\mathrm{b}}$ & $2382.56 \pm 633.244^{\mathrm{a}}$ \\
Pre-baked and frozen & $1.515 \pm 0.015^{\mathrm{b}}$ & $49 ., 708 \pm 2,710^{\mathrm{a}}$ & $2439.060 \pm 286.261^{\mathrm{a}}$ \\
\hline
\end{tabular}

RIF = Rice flour CAS = Cassava starch MAS = Maize starch; ${ }^{\mathrm{x}}$ Arithmetical average \pm Standard deviation; ${ }^{\mathrm{x}}$ Averages in the same column with different letters differ overridden by Tukey test $(\mathrm{p}<0.05)$. 
Table 9. Results of physicochemical and nutritional analyses of gluten-free bread and muffin and gluten-free bread and chocolate cake (Marilis ${ }^{\circledR}$ brand).

\begin{tabular}{|c|c|c|c|c|}
\hline Analysis & Gluten-free bread & Gluten-free bread ${ }^{*}$ & Gluten-free muffin & Gluten-free chocolate cake* \\
\hline Moisture and volatiles (\%) & 33.02 & $\mathrm{NI}^{* *}$ & 24.29 & $\mathrm{NI}^{\star \star}$ \\
\hline Ash (\%) & 1.12 & $\mathrm{NI}^{* *}$ & 2.68 & $\mathrm{NI}^{* *}$ \\
\hline Carbohydrates (\%) & 51.73 & 36.67 & 39.92 & 75.75 \\
\hline Proteins (\%) & 4.27 & 2.83 & 7.70 & 4.85 \\
\hline Fat total $(\%)$ & 5.21 & 4.33 & 19.89 & 7.58 \\
\hline Saturated fat (\%) & 1.63 & 0 & 10.53 & 1.12 \\
\hline Trans fat (\%) & $<0.10$ & 0 & 0.15 & 0 \\
\hline Dietary fiber (\%) & 4.65 & 0 & 5.52 & 0 \\
\hline Energetic value (kcal.100 g $\left.{ }^{-1}\right)$ & 270.89 & 196.97 & 369.49 & 390.62 \\
\hline Calcium (mg.100 g $\left.{ }^{-1}\right)$ & 14.88 & $\mathrm{NI}^{\star *}$ & 268.48 & $\mathrm{NI}^{* *}$ \\
\hline Iron $\left(\mathrm{mg} .100 \mathrm{~g}^{-1}\right)$ & 3.55 & $\mathrm{NI}^{* *}$ & 6.75 & $\mathrm{NI}^{* *}$ \\
\hline Sodium $\left(\mathrm{mg} .100 \mathrm{~g}^{-1}\right)$ & 346.13 & 426.67 & 591.80 & 48.48 \\
\hline
\end{tabular}

*Source: Marilis (2007); ${ }^{* *}$ NI: not informed.

The reason why the samples analyzed did not show significant difference may be related to the short period of frozen storage (30 days).

In order to verify whether the differences found in the instrumental analyses between baked products and pre-baked and frozen products were sensorially perceived, the triangular test was conducted on samples of gluten-free bread and muffin.

Twelve tasters participated in the analysis, of which only four identified a different sample from bread and one identified the sample different from muffin. Based on chi-square tests, the minimum number of correct answers to establish significant difference between samples is eight $(\mathrm{p}<0.05)$. Therefore, there was no significant difference between the samples of baked bread and muffin and the samples of pre-baked and frozen bread and muffin. Thus, the products may be frozen without losing their sensory quality.

\subsection{Physicochemical analysis of bread and muffin}

In order to verify the physicochemical and nutritional characteristics of the bread and muffin, analyses were performed as described in Table 9, for a comparison with the gluten-free bread and chocolate cake marketed by Marilis ${ }^{\circ}$ company (São Paulo, Brazil).

The analyses of moisture and ash are in accordance with the current law, which determines 35 and $11.4 \%$ as maximum values of moisture and ash, respectively (BRASIL, 2005).

Making a comparison between the results of the analyses of gluten-free bread and gluten-free bread marketed by the Marilis ${ }^{\circ}$ company, it may be observed that the bread developed in this study presented greater quantities of dietary fiber, carbohydrates, protein, fat, and consequently energetic value. A larger amount of protein is originated from the use of eggs and soybean extract. These ingredients were used precisely to meet the shortage of these nutrients in the cassava and other starches used. A larger amount of dietary fiber and protein makes the product more interesting nutritionally if compared with the product marketed by Marilis ${ }^{\bullet}$.
From the comparative analysis for the gluten-free muffin, it may be verified that the muffin developed in this research presented greater quantities of dietary fiber, protein, fat, and sodium. A larger amount of protein is originated from the use of eggs and soybean extract. The results also showed an increase in the amount of dietary fiber what could be related with the presence of resistant starch. As with the bread, a larger amount of dietary fiber and protein makes the product more interesting nutritionally if compared with the commercial sample.

\section{Conclusions}

The chemical composition of gluten-free bread showed values close to the gluten-free bread of Marilis ${ }^{\circledR}$ brand, used as reference. The addition of the soybean extract, rich in protein, was made in order to compensate the low percentage of this nutrient.

Considering the results of the sensory analysis of acceptance and the purchase intention of the bread analyzed, it may be concluded that the formulation relating to the optimal simultaneous point between instrumental measurements $(20 \%$ RIF + 30\% CAS + 50\% MAS) obtained the best results. From this formulation, the sensory analysis was performed for evaluating the purchase intention of common consumers and celiac consumers presenting averages of $6.96 \pm 1.71$ and $6,71 \pm 1.69$, respectively, in a nine point hedonic scale, and $65 \%$ of consumers would probably or certainly buy the bread.

The chemical composition of the gluten-free muffin showed values close to the gluten-free chocolate cake of Marilis ${ }^{\oplus}$ brand, used as reference, with a higher content of dietary fiber.

The sensory evaluation of the muffin conducted by common and celiac consumers showed averages of $7.76 \pm 1.07$ and $8.35 \pm 0.79$, respectively, in a nine point hedonic scale, in which more than $90 \%$ of the consumers would probably or certainly buy the muffin.

\section{References}

ASSOCIATION OF OFFICIAL ANALYTICAL CHEMISTS - AOAC. Official methods of analysis of AOAC International. 16. ed. Gaitheersburg, 1997. 
ASSOCIATION OF OFFICIAL ANALYTICAL CHEMISTS - AOAC. Official Methods of the Association of the Agricultural Chemists. 17. ed. Gaitheersburg, 2000. v. 2.

BOBBIO, F. O.; BOBBIO, P. A. Introdução à química de alimentos. 3. ed. São Paulo: Varela, 2003.

BRASIL. Resolução RDC nº. 263, de 22 de setembro de 2005. Regulamento técnico para produtos de cereais, amidos, farinhas e farelos. Diário Oficial da União, Brasília, DF, 23 set. 2005.

EL-DASH, A.; MAZZARI, M. R.; GERMANI, R. Tecnologia de farinhas mistas: uso de farinha mista de trigo e mandioca na produção de pães. EMBRAPA-SPI, 1994. 88 p. v. 1.

ESCOUTO, L. F. S.; CEREDA, M. P. Elaboração de pré-mistura de massa para pão sem glúten a partir de derivados energéticos de mandioca. 2004. 84 f. Dissertação (Doutorado em Agronomia/ Energia na Agricultura)-Faculdade de Ciências Agronômica, Universidade Estadual Paulista, Botucatu, 2004.

ESTELLER, M. S.; LANNES, S. C. S. Parâmetros complementares para fixação de identidade e qualidade de produtos panificados. Ciência e Tecnologia de Alimentos, v. 4, n. 25, p. 802-806, 2005.

ESTELLER, M. S.; ZANCANARO JUNIOR, O.; LANNES, S. C. S. Bolo de "chocolate" produzido com pó de cupuaçu e kefir. Revista Brasileira de Ciências Farmacêuticas, v. 42, n. 3, 2006.

GALLAGHER, E.; GORMLEY, T. R.; ARENDT, E. K. Crust and crumb characteristics of gluten free breads. Journal of Food Engineering, v. 56, n. 2-3, p. 153-161, 2003.

INSTITUTO ADOLFO LUTZ. Normas Analíticas do Instituto Adolfo Lutz: métodos químicos e físicos para análise de alimentos. São Paulo: IAl, 1985.

LAAKSONEN, T.; ROOS, Y. H. Thermal, dynamic-mechanical, and dielectric analysis of phase and state transitions of frozen wheat doughs. Journal of Cereal Science, v. 32, p. 281-292, 2000.
MARILIS. Produtos sem gluten. Disponível em: <http://www. semgluten.com.br/html/marilis.htm>. Acesso em: 1 ago. 2007.

MERIC, L. et al. Cryoresistance of baker's yeast Saccharomyces cerevisiae in frozen dough: contribution of cellular trehalose. Cereal Chemistry, v. 72, p. 609-615, 1995.

PAVANELLI, A. P.; CICHELLO, M. S.; PALMA, E. J. Emulsificantes como agentes de aeração em bolos. [S.l.]: Oxiteno S/A Indústria e Comércio, 2000. Artigo Técnico, ART AL004 - 06/00.

RÄSÄNEN, J.; HÄRKÖNEN, H.; AUTIO, K. Freeze-thaw stability of prefermented frozen lean wheat doughs: effect of flour quality and fermentation time. Cereal Chemistry, v. 72, p. 637-642, 1995.

SARMENTO, S. B. S. Caracterização da fécula de mandioca (Manihot esculenta C.) no período de colheita de cultivares de uso industrial. 1997. 162 f. Tese (Doutorado em Bromatologia)Faculdade de Ciências Farmacêuticas, Universidade de São Paulo, São Paulo, 1997.

SLUIMER, I. P. Principles of dough retarding. Bakers' Digest, v. 55, n. 4, p. 6-8, 1981.

SUNADA, C. S. S. et al. Pré-mistura para produção do pão sem glúten baseada em derivados da mandioca. In: CONGRESSO BRASILEIRO DE MANDIOCA, 11., 2003, Campo Grande. Anais...

TESCH, C. Para quem o glúten faz mal? Disponível em: $<$ http://www. salamedica.com/nutricao-glutem.php>. Acesso em: 17 abr. 2006.

UNIVERSIDADE DE SÃO PAULO - USP. Pesquisa da USP desenvolve novo tipo de pão congelado. Disponível em: $<\mathrm{http}: / /$ www.herbario.com.br/dataherb07/1312paocongel.htm>. Acesso em: 20 mar. 2007.

VARRIANO-MARSTON, E.; HSU, K. H.; MAHDI, J. Rheological and structural changes in frozen doughs. Baker's Digest, v. 54, p. 32-41, 1980. 